\title{
I dentification of biovars of Brucella abortus in aborted cattle and buffaloes herd in Sri Lanka
}

\author{
Priyantha M.A.R. \\ Veterinary Research Institute, \\ PO Box 28, Peradeniya, Sri Lanka \\ E-mail: appuhami1974@yahoo.com \\ Received:27-06-2011, Accepted: 17-07-2011, Published Online: 23-10-2011 \\ doi: $10.5455 /$ vetworld.2011.542-545
}

\begin{abstract}
Bovine brucellosis is an endemic disease in Sri Lanka, caused by Brucella abortus and had been reported all part of the country for last six decades. Since available biovar is still unknown, the objective of the study was to identify the biovar of B.abortus from sporadically aborted cattle and buffaloes. Samples were collected from 18 aborted herds out of 19 herds of Cattle and Buffaloes in the year 2010. Rose Bengal plate test and Compliment Fixation test were carried out. Milk, vaginal swabs, placental contents and aborted fetus were collected and cultured by conventional bacteriological methods. The detection of biovars were based on growth on Thionin and Bacto fuschin, $\mathrm{CO}_{2}$ requirement, $\mathrm{H}_{2} \mathrm{~S}$ production, serum agglutination with Brucella negative, A,M and R reference antiserum. Eighteen herds investigated out of 19 herds reported, 11 herds were serologically positive for brucellosis (61.11\%) and only Brucella abortus were isolated from 8 individuals from six herds. All were identified as Biovar 3 of Brucella abortus.
\end{abstract}

Key words: Bovine, Brucellosis, Sri Lanka, Endemic disease, Occupational health Hazard, Zoonoses, Laboratory Techniques, Biovars.

\section{Introduction}

Bovine brucellosis, caused by bacterium Brucella abortus is an important zoonotic disease in many developing countries (Smits, H.L. and Kadri, S.M.,2005). The disease has been reported in different provinces in India, Pakistan and Bangladesh (Abubakar, M. et al, 2010., Mantur, B.G., and Amaranth, S.K., 2008., Rahman,et al, 2006). Brucellosis is considered an threatening disease in Sri Lanka (Priyantha et al,2008) and had been introduced through importation of cattle during the Second World War (De Alwis,1993). In Sri Lanka, first Clinical outbreak was reported in 1956 and subsequently, bovine brucellosis has become an endemic disease in the country, causing severe economical impact to current livestock industry (Gajanayake et al, 2000). In the year 2010, 19 herds were reported with abortion and 18 herds were investigated for the present study. However, isolated clinical cases had reported all over the dry zone in year 2010 although laboratory confirmation was not carried out (Veterinary Epidemiological Bulletin, 2010).

Objective of this study was to identify available biovars of Species Brucella abortus from aborted herds and to understand different livestock hosts in which Brucella abortus survives in the environment (Qiunn etal, 1994).

\section{Materials and methods}

Eighteen herds out of 19 herds in the Sri Lanka were investigated and samples were collected from cattle and buffaloes with the history of abortion nationwide. Information were received from regional Government Veterinary offices when sporadic abortions continuing in particular regions, is the routine disease reporting system established in the country. Samples were collected 1-14 days from day of abortion up to less than 6 weeks (Nielsen \&Duncan, 1990). Serum, milk, vaginal swabs and aborted fetus were collected from individual animal.

Serology: Complement Fixation Test (CFT) is the gold standard test for serological diagnosis of brucellosis in cattle (OIE, 2009). Serums were first tested by the Rose Bengal Plate test and confirmation was done by the CFT according to method described by Alton et al, 1988. RBPT antigen derived from S 99 imported from Weighbridge laboratory, UK produced in the Veterinary Research Institute, Sri Lanka according to the methods described in the OIE Manual of Standards for diagnostic tests and vaccines (2008). 
Identification of biovars of Brucella abortus in aborted cattle and buffaloes herd in Sri Lanka

Table-1. The summary of data collected from different herds' investigation

\begin{tabular}{|c|c|c|c|c|c|}
\hline Location & Type of animals & Herd size & $\begin{array}{l}\text { Management } \\
\text { system }\end{array}$ & Age & $\begin{array}{c}\text { Isolation of } \\
\text { B rucella organism }\end{array}$ \\
\hline Ambilipitiya & Sahiwal and Jursey crosses & $<25$ & $\begin{array}{l}\text { Extensive and } \\
\text { semi extensive }\end{array}$ & 3-12 & - \\
\hline $\begin{array}{l}\text { Anamaduwa } \\
\text { Anamaduwa }\end{array}$ & Jursey crosses, Frersein crosses & $<25$ & extensive & $3-8$ & - \\
\hline (Herd with stud ) & Sahiwal crosses & $25-50$ & extensive & $2-7$ & - \\
\hline Buttala & Indegenois & $25-50$ & extensive & $2-8$ & \\
\hline Wellawaya & Indegenoius & $25-50$ & & & + \\
\hline Parasangaswewa & Sahiwal and sahiwal crosses & $<25$ & $\begin{array}{l}\text { Extensive } \\
\text { (S } 19 \text { vaccinated) }\end{array}$ & $2-8$ & \\
\hline Oyamaduwa & Sahiwal crosse and sahiwal & $25-50$ & extensive & $2-8$ & \\
\hline Karuwalagaswewa & Indigenous, Sahival crosses, Jursey crosses & $25-50$ & extensive & $2-9$ & + \\
\hline Karuwaklagaswewa & Sahiwal crosess & $<25$ & extensive & $2-9$ & \\
\hline Murukkan & Local crosses & $25-50$ & extensive & 3-11 & - \\
\hline Mannar 1 & Local crosses & $25-50$ & extensive & $3-9$ & \\
\hline Mannar 2 & Local crosses & $<25$ & extensive & $3-9$ & \\
\hline
\end{tabular}

Bacterial isolation: B.abortus was isolated from vaginal swabs, milk and aborted fetus by conventional methods described by Alton et al, (1988). Commercial Brucella agar (Oxoid CMO169) was used as base for both selective and non selective medium with $4 \%$ sheep blood. The OXOID CMO 169 selective supplement was added only for selective media to inhibit contamination. The isolated organisms were tested by biochemical tests and serum agglutination test with Brucella reference antiserum brought from International reference laboratory, France. Milk samples were collected directly to sterile bottles $(20$ $\mathrm{ml}$ each) from each teat of aborted cows aseptically. The samples were centrifuged at $6000 \mathrm{~g}$ for 15 minutes. Both deposited and cream layer were cultured on selective and non selective media, were incubated at $10 \% \mathrm{CO}_{2}$ and without $\mathrm{CO}_{2}$ as described by Alton et al, 1988. Sterile, $10 \mathrm{~cm}$ long swabs were used for this purpose. Samples were (Five samples from each and pooled) collected directly from the vaginal wall, cultured on Brucella specific medium and incubated at $37^{\circ} \mathrm{C}$ with and without $10 \% \mathrm{CO}_{2}$ incubation as described by Alton et al,1988. The aborted fetus is considered as one of the best sample to isolates Brucella in cattle and Buffalo (Nielsen \& Duncan,1990). Inoculations were made from aborted fetuses specially from stomach contents, lungs, spleen, liver, on Brucella specific and nonspecific medium as described by Alton et al, 1988. However, collection of fetuses from extensive herds were difficult as fetuses were eaten by other animals.

The identification of biovar of Brucella was

done by the method described by Alton et al,1988, based on growth on Thionin and Bacto fuschin, $\mathrm{CO}_{2}$ requirement, $\mathrm{H}_{2} \mathrm{~S}$ production, reaction with Brucella negative anti-serum and $\mathrm{A}, \mathrm{M}$ and $\mathrm{R}$ reference antisera.

\section{Results}

Eighteen aborted herd were investigated (Out of 19 reported in 2010), 11 herds were identified as serologically positive for brucellosis $(61.11 \%)$. The seropositive animals were detected in herds at Dambulla, Anamaduwa, Mihintale, Sippukulam, Buttala, Mannar and Bingiriya and their Complement Fixation Test (CFT) titers were varied from 1:16 to 1:2018. There were nine Brucella abortus organism isolated from six different herds and biovar 3 was isolated from milk, aborted fetus and vaginal swabs.

\section{Discussion}

Brucellosis is an endemic disease specially in dry zone (Priyantha et al,2008, De Alwis et al,1989), where the highest density of cattle reported in the country. The serological brucellosis in local herds has been studied at regional level, although surveillance on brucellosis is still a subject area of priority. It was apparent that brucellosis is the main cause of sporadic abortion in cattle at last trimester of pregnancy and $61.11 \%$ of aborted herds examined were found positive serologically. Similar information was published by Priyantha et al in 2010, indicated that Brucella abortus was the main cause of abortion in water buffaloes. Furthermore, Brucellosis is considered major reproductive disease of cattle in Dry zone of Sri Lanka 
Identification of biovars of Brucella abortus in aborted cattle and buffaloes herd in Sri Lanka

Table-2. Biochemical and serological characters of the isolated Brucella cultures.

\begin{tabular}{|c|c|c|c|c|c|c|c|}
\hline Brucella Isolates & $\begin{array}{l}\mathrm{CO2} \\
\text { requirement }\end{array}$ & $\begin{array}{c}\mathrm{H} 2 \mathrm{~S} \\
\text { production }\end{array}$ & $\begin{array}{l}\text { Growth on } \\
\text { Thionin }\end{array}$ & $\begin{array}{c}\text { Growth on } \\
\text { Basic Fuschin }\end{array}$ & $\begin{array}{c}\text { Agglutination } \\
\text { in SeraA }\end{array}$ & $\begin{array}{c}\text { Agglutination } \\
\text { in SeraM }\end{array}$ & $\begin{array}{c}\text { Agglutination } \\
\text { in SeraR }\end{array}$ \\
\hline 2010/Anu/01 & + & + & + & + & + & - & - \\
\hline 2010/Bad/02 & + & + & + & + & + & - & - \\
\hline 2010/Put/04 & + & + & + & + & + & - & - \\
\hline 2010/Put/05 & + & + & + & + & + & - & - \\
\hline 2010/Put/06 & + & + & + & + & + & - & - \\
\hline 2010/Kur/09 & + & + & + & + & + & - & - \\
\hline S 19 control & - & + & - & + & + & - & - \\
\hline
\end{tabular}

for long time, (Priyantha et al, 2008, Kumaraswami, 1971).

The isolation of Brucella abortus were from nine individuals, representing six different herds (Table-3). Most isolates were from indigenous and extensive or semi extensive herds of dry zone and only one isolate from Bingiriya. The rearing indigenous animals are found in dry zone (Priyantha et al, 2008). Those herds are sent to jungle or pasture land around big tanks in the region, shearing same pasture by different herd and cross contamination is common (Priyantha et al, 2008). The oral contamination which is the most common method of transmission in an extensive herd (Abubakar, M.et al, 2010. Nielsen \& Duncan, 1990). Higher stocking density has been cited as an important factor influencing transmission and persistence of infection (Nielsen \&Duncan, 1990).

The important finding of this study was detection of latent carriers of Brucella abortus. There were three animals detected at Mundalama and one detected at Pannala. They were excreted bacteria through milk and reproductive secretion although not detected by RBP test. The latent carrier may cause detrimental results in control program (Nielsen \&Duncan, 1990., Dolan L.A.et al, 1980), reported by different authors in different hosts (Huurne et al, 1993., Verma et al, 2000.,Dolan,L.A.,1980). Meanwhile calves infected by B.abortus in utero or after ingestion of infected milk may acquire a persistent infection, remain negative until calving or abortion (Huurne et $a l, 1993)$. However, those in this study were remain negative for serologically even at calving and excreting organism with milk and reproductive secretion, which needs to be study further.

The causative bacteria, Brucella abortus has been isolated from at least nine species of domestic livestock (Nielsen \&Duncan, 1990). All isolated were as biovar 3 by biochemical and agglutination tests described by Alton et al, 1988, (Table-3) out of 7 biovars identified from B.abortus (OIE, 2009). Brucella abortus biovar 3, only biovar was given positive for $\mathrm{CO}_{2}$ requirement for growth, $\mathrm{H}_{2} \mathrm{~S}$ production, growth on Thionine and basic fuschin reagent. It was given positive results for Brucella type A antisera and negative for $\mathrm{M}$ and $\mathrm{R}$ antisera. All isolates required $\mathrm{CO}_{2}$ for growth on artificial media and produced $\mathrm{H}_{2} \mathrm{~S}$, described as biovar1,2, 3,4 or 9 of B.abortus. Also all nine Isolates were grown on Thionin and basic fuchin given concentration by Alton et al,1988 and categorized under biovar 3 after the agglutination test of A.M and R. Biovar 1 of Brucella abortus is appeared as most common and widely distributed in the world (Nielsen \&Duncan, 1990). The distribution is varied with one country to the other and Only 1.2 and 4 are reported in USA while biovar 3 and 7 are not yet reported in England (Nielsen \&Duncan, 1990). In the literature published, Only biovar 1,3,5 of Brucella abortus have been reported in India, which is considered as the source of brucellosis in Sri Lanka during the period of second world war (Perumal

Table-3. Details of origin of different isolates of Brucella abortus from the field.

\begin{tabular}{llll}
\hline Isolate & Location & Type of Sample & CFT titer of individual animal \\
\hline 2010/Anu/01 & Sippukulam & Aborted fetus & $1: 1024$ \\
2010/Bad/02 & Wellawaya & Aborted fetus & Hemolysed \\
2010/Mat/03 & Dambulla & Milk & $1: 1024$ \\
2010/Put/04 & Karuwalagaswewa & Milk & $1: 2048$ \\
2010/Put/05 & Mundalama & Milk, Vaginal swabs & Negative \\
2010/Put/06 & Mundalama & Milk, Vaginal swabs & Negative \\
2010/Put/07 & Mundalama & Milk, Vaginal swabs & $1: 2048$ \\
2010/Put/08 & Mundalama & Milk & Negative \\
2010/Kur/09 & Pannala & Milk & Negative \\
\hline
\end{tabular}


Pillai,1957). However, in the taxonomy sequential flow of Brucella abortus biovar 3 is found at the mid level. In contrast, biotype 2 has the greatest environment demand, considered possible progenitor of the biotype while biovar 5 is at the end of the line (Nielsen \&Duncan, 1990). The biovar 3 is mainly associated with cattle and buffaloes (Nielsen \& Duncan, 1990, Alton et al, 1988). Eradication must be emphasized on those specific host than rest of the range of hosts of Brucella abortus which survives in the environment. Brucella infected milk may cause negative effect on human health (Emerging Infectious Disease,1997) though human brucellosis had not been reported in Sri Lanka. However, biovar 3 had been isolated from human cases (L.Valdezate, 2009) and risk has not been evaluated locally.

\section{Conclusion}

The study concluded that biovar 3 of Brucella abortus was identified in local cattle of Sri Lanka mainly in extensively reared cattle in 2010, provided basic information on eradication of Brucella in future. Further studies are necessary about the epidemiology, pathogenesis and molecule characterization of the organisms to eradicate the disease from the certain region or country.

\section{Acknowledgements}

Author would like to acknowledge all the Veterinary Investigation Officers attached to the Animal Health Division and Government Veterinary Surgeon for their kind corporation, Also the Dept. of AP\& $\mathrm{H}$ for granting fund for the project.

\section{References}

1. Abubakar M.Javed,A.M.,Hussain,M.,Ehtishan.,Ul Haq.,Ali Q.(2010). Serological evidence of B.abortus prevalence in Panjab Province, Pakistan. A cross sectional study. Transboundry Emerging Disease.57. (6) 443-7.

2. De Alwis, M.C.L., Wijewrdane B,D.R., Wijewardana T.G., (1993).The status of Bovine brucellosis in Sri Lanka-A Review, Sri Lanka Veterinary Journal.40(2), 1-5.

3. Dolan, L.A. (1980). Latent carrier of Brucellosis. Veterinary Records.106:241-243.

4. First International conference on emerging zoonoses (1997). Emerging Infectious Disease. 3(2): 229-238.

5. Gajanayeke. S.,De ALwis, M.C.L. Wijewrdana T.G.,
Jeraruban M.G.(2000) Bovine Brucellosis in Sri Lanka: An economical evaluation of losses and proposed eradication program. Sri Lanka Vet Journal.47 (1A); 13-20.

6. Huurne,A.A., Meiyer,M., N.A. Dijkerman, (1993).Latency of B.abortus cause problem in carrier control. Tijdcher Diergeneeshed. 21:1:118, Pp 679-683.

7. Kumaraswasmi, S (1971). The significance brucellosis in Ceylon. Ceylon Vet Journal 19:119-123.

8. Mantur, B.G., Amaranath, S.K.(2008). Brucellosis reemerging zoonosis, Journal of Bioscience, vol.33.No:04. Pp. 539-547.

9. Manual for Diagnostic test and Vaccine for Terrestrial Animals (2008). $6^{\text {th }}$ Edition. Vol. 1 \&2.

10. Neilson and Duncan (1990).Animal Brucellosis CRS press, Inc., 2000 Corporate Blvd. N. W.Boca Raton, Florida 33431

11. Perumali Piilai, Kumaraswami (1957).Infertility studies among dairy animals in Ceylon. Ceylon Vet. Journal, 5:8-18.

12. Priyantha M. A. R., A. A. Vipulasiri, Samarakoon S.A.T.C Fasi., Thaiba., Nowshard., Shifaya., Senewirathne (2010). The serological survey on bovine brucellosis at slaughter houses in Eastern Province, Sri Lanka. Proceeding of Fifth Asian Biotechnology conference.Pp25-26.

13. Priyantha M. A. R., G. A. Deepal, Chandana, S. Puvanendran, M. I. Wijemuni, G.A.Gunawardana, G. S. Appuhamy, and P. S. Fernando (2008). Spacial distribution of Brucella abortus stereotyping cases in cattle during 20012007; A case study of using GIS in improving the recommended control strategies in Sri Lanka. Fifth National Symposium on Geo-Informatics for sustainable Development, Colombo, pp135-148.

14. Priyantha M.A.R., Gunawardana G.A., Puvanenderan S. Wijemuni M.I. and P.S.De Alwis.(2010).Serological Detection of Leptospira Serovars from aborted water Buffaloes in Sri Lanka. Proceeding of $9^{\text {th }}$ World Buffalo Congress: Infectious diseases. Pp : 480-483.

15. Quinn,P.J., Carter, M.E., Markey,B., Carter, G.R.(1994). Clinical Veterinary Microbiology.Rahman, M.S.,Han.J.C., Park, J. Lee, J.H., eo, S.K., Chae, J.S.(2006).Prevalence of brucellosis on its association with reproductive problem in cows in Bangladesh.Vet.Records.159:180-182.

16. Smits, H.L., Kadri, S.M. (2005) Brucellosis in India: a deceptive infectious disease. Indian J. Med. Res 122, November 2005.Pp.375-384.

17. Valdezate,S., Ana Navarro., Pilar Villalón, Gema Carrasco, and Juan A. Saéz-Nieto(2000) Epidemiological and Phylogenetic Analysis of Spanish Human Brucella melitensis Strains by Multiple-Locus Variable-Number Tandem-Repeat Typing, Hypervariable Octameric Oligonucleotide Fingerprinting, and rpoB Typing. Journal of clinical Microbiology. Vol 48,No:8.,2734-2740.

18. Verma,S., Katoch,R.C., Sahrma,M., Nigal P.(2000) Abortion and infertility in domestic livestock due to brucellosis in Himachal Pradesh, India. Veterinarski Arhiv. 70 (2), Pp.75-82.

19. Veterinary Epidemiological Bulletin, Sri Lanka (2010) Vol: 3, No: 02 . 